DOI: $10.17816 /$ KMJ2019-740

\title{
Relationship Between Delta Troponin I Levels And In-Hospital Cardiovascular Endpoints In Acute $S T$ Elevation Myocardial Infarction
}

\author{
Aydin Ercan ${ }^{1 *}$, Osken Altug², Yaylaci Selcuk³, Sahinkus Salih", \\ İbrahim Kocayiğit ${ }^{4}$, Nurgul Keser ${ }^{4}$, Gunduz Huseyin ${ }^{4}$ \\ 'Department of Cardiology, Vakfikebir State Hospital, Trabzon, Turkey; \\ ${ }^{2}$ Department of Cardiology, Dr. Siyami Ersek Cardiovascular \\ and Thoracic Surgery Center, Istanbul, Turkey; \\ ${ }^{3}$ Department of Internal Medicine, Sakarya University Education \\ and Research Hospital, Sakarya, Turkey; \\ ${ }^{4}$ Department of Cardiology, Sakarya University Education \\ and Research Hospital, Sakarya, Turkey
}

\begin{abstract}
Objectives. In this study, we investigated the relationship between the rate of increase in troponin I levels and inhospital cardiovascular endpoints (outcomes) in patients with $S T$-elevation myocardial infarction (STEMI).

Methods. Eighty-four patients with acute STEMI who received thrombolytic treatment or who underwent primary percutaneous coronary intervention (PCI) were enrolled. After admission to hospital, delta troponin I levels, which were determinedby serial measurements after 2, 4, and $6 \mathrm{~h}$ of admission, and in-hospital major cardiovascular events were evaluated.

Results. There were 35 (41.7\%) patients in the thrombolytic group and 49 (58.3\%) patients in the primary PCI group. As major cardiovascular endpoints, death from cardiovascular events was seen in 7 (8.3\%) patients, stroke/transient ischemic attack in $2(2.4 \%)$, recurrent ischemia in $5(6 \%)$, arrhythmia in $8(9.5 \%)$, and urgent revascularization was performed in $5(6 \%)$ cases. In patients with arrhythmia, ventricular fibrillation was seen in $3(3.6 \%)$ patients, atrial fibrillation in $3(3.6 \%)$, and ventricular tachycardia in $2(2.4 \%)$ patients. The ventricular septal defect was observed only in $1(1.2 \%)$ patient as a mechanical complication, and the patient underwent urgent surgery. The analysis of all patients and sub-groups of thrombolytic and primary PCI patients revealed no statistically significant difference between delta troponin I levels at time intervals of $(0-2),(0-4)$, and $(0-6) \mathrm{h}$ and in-hospital major cardiovascular endpoints $(\mathrm{p}>0.05)$.

Conclusion. The analysis of delta troponin I levels is not a predicting factor of in-hospital endpoints (outcomes) in patients with STEMI treated by thrombolytic therapy or primary PCI. Randomized controlled studies with a larger study population are needed on this subject.
\end{abstract}

Keywords: Delta troponin I, ST Elevation Myocardial Infarction.

Для цитирования: Ercan A., Altug O., Selcuk Ya.Relationship Between Delta Troponin I Levels And In-Hospital Cardiovascular Endpoints In Acute ST Elevation Myocardial Infarction. Kazan medical journal. 2019; 100 (5): 740-745. DOI: 10.17816/ KMJ2019-740.

\footnotetext{
Связь между приростом уровня тропонина I и госпитальными кардиоваскулярными исходами при остром инфаркте миокарда с подъёмом сегмента $\boldsymbol{S T}$

А. Эркан ${ }^{1}$, О. Алтуг ${ }^{2}$, Я. Сельчук ${ }^{3}$, С. Салих ${ }^{4}$, И. Косаигит ${ }^{4}$, Н. Кесер ${ }^{4}$, Г. Хусейин ${ }^{4}$

${ }^{1}$ Государственная больница г. Вакфыкебир, Трабзон, Турция;

${ }^{2}$ Центр сердечно-сосудистой и торакальной хирургии им. доктора Сиями Эрсека, Стамбул, Турция;

${ }^{3}$ Кафедра внутренних болезней, Университетская учебно-исследовательская больница провинции Сакарья, Сакарья, Турция;

${ }^{4}$ Кафедра кардиологии, Университетская учебно-исследовательская больница провинции Сакарья, Сакарья, Турция
} 


\section{Реферат}

Цель. В этом исследовании мы изучали взаимосвязь между скоростью увеличения уровня тропонина I и госпитальными кардиоваскулярными конечными точками (исходами) у пациентов с инфарктом миокарда с подъёмом сегмента $S T$ (STEMI).

Методы. 84 пациента со STEMI, которым были проведены тромболитическая терапия или первичное чрескожное коронарное вмешательство (ЧКВ), были включены в исследование. После поступления в больницу оценивали прирост уровня тропонина I, который определяли путём серийных измерений через 2,4 и 6 ч после госпитализации, а также регистрировали тяжёлые сердечно-сосудистые события за период стационарного лечения.

Результаты. 35 (41,7\%) пациентов были включены в группу тромболитической терапии, 49 (58,3\%) пациентов - в группу первичного ЧКВ. Среди основных сердечно-сосудистых конечных точек смерть от сердечно-сосудистых событий зарегистрирована у 7 (8,3\%) пациентов, инсульт/транзиторная ишемическая атака - у 2 (2,4\%), рецидивирующая ишемия - у $5(6 \%)$, аритмия - у 8 (9,5\%), экстренная реваскуляризация проведена в 5 (6\%) случаях. У пациентов с аритмией фибрилляция желудочков отмечена у 3 (3,6\%) человек, фибрилляция предсердий - у 3 (3,6\%), желудочковая тахикардия - у 2 (2,4\%) пациентов. Дефект межжелудочковой перегородки как механическое осложнение зафиксирован только у $1(1,2 \%)$ пациента, при этом была проведена срочная операция. Анализ всех пациентов и их подгрупп с тромболитической терапией и первичным ЧКВ не выявил статистически значимой разницы между приростом уровня тропонина I во временных интервалах 0-2, 0-4 и 0-6 ч и частотой развития госпитальных кардиоваскулярных конечных точек ( $p>0,05)$.

Вывод. Анализ прироста уровня тропонина I не является прогностическим фактором госпитальных конечных точек (исходов) у пациентов с STEMI, получавших тромболитическую терапию или первичное ЧКВ; необходимо проведение рандомизированных контролируемых исследований с участием большой популяции пациентов.

Ключевые слова: прирост тропонина I, инфаркт миокарда с подъёмом сегмента ST.

Для цитирования: Эркан А., Алтуг О., Сельчук Я. и др. Связь между приростом уровня тропонина I и госпитальными кардиоваскулярными исходами при остром инфаркте миокарда с подъёмом сегмента ST. Казанский мед. ж. 2019; 100 (5): 740-745. DOI: 10.17816/KMJ2019-740.

Introduction. Today, cardiovascular diseases are the most common cause of mortality and morbidity [1]. In recent years with the advances in $S T$-elevation myocardial infarction (STEMI) treatment, 30-day mortality has reduced to $<6 \%$ in thrombolytic treatment patients and $<4 \%$ in primary percutaneous coronary intervention (PCI) patients [2]. Troponin I (cTn-I) is an infraction indicator exclusive to the myocardial muscle and cTn-I blood levels increase within $2-4 \mathrm{~h}$ after acute myocardial infarction, peak at the $24^{\text {th }} \mathrm{hr}$, remain high for 2-3 weeks [3], and provide important information for the diagnosis of myocardial infarction and prognosis [4].

Reichlin et al. (2011) identified that absolute and relative increase in cTn-I levels were useful in the diagnosis of acute myocardial infarction [5]. Earlier studies have revealed a strong relationship between peak cTn-I levels and cardiovascular events in myocardial infarction [6]. However, the relationship between the rate of increase in cTn-I levels and cardiovascular endpoints in acute myocardial infarction is unknown.

The purpose of our study was to compare the relationship between relative increase of troponin-I levels calculated in STEMI patients and in-hospital cardiovascular endpoints.
Subjects and method. Eighty-four patients admitted to the Sakarya University Training and Research Hospital Cardiology Clinic between 2011 and 2013 with acute STEMI, thrombolytic or primary PCI was performed by scanning retrospective file records of patients. There were 35 patients in thrombolytic group and 49 patients in primary PCI group. The patients who were included in the study, except for the deaths, were followed up for an average of 5-7 days in the Coronary Intensive Care Unit for 2-3 days. Laboratory values and serial cTn-I measurements at 2, 4, and $6 \mathrm{~h}$ after admission were obtained. Extension of the door-balloon time up to 120 minutes in STEMI reduced the number of patients receiving thrombolytic therapy and limited the number of patients included in the study. Since the authors are not aware of any studies in that exprole the predicting value of early changes in troponin levels regarding in-hospital cardiac outcomes in STEMI patients, the sample size was not calculated.

Approval of the Sakarya University Medical Faculty Ethics Committee was obtained for the study protocol.

Inclusion Criteria.

1. Presence of ischemic chest pain with the duration not exceeding $4 \mathrm{~h}$. 
Теоретическая и клиническая медицина

Table 1. Demographic and clinical properties of the cases included in the study

\begin{tabular}{|c|c|c|c|c|}
\hline Parameters & Total $(n=84)$ & Thrombolytic $(\mathrm{n}=35)$ & PCI $(n=49)$ & $\mathrm{p}$ value \\
\hline Age, years & $58.8 \pm 11.9$ & $60.3 \pm 12.9$ & $57.8 \pm 11.2$ & 0.484 \\
\hline $\begin{array}{l}\text { Sex } \\
\text { Male } \\
\text { Female }\end{array}$ & $\begin{array}{l}65(77.4) \\
19(22.6)\end{array}$ & $\begin{array}{c}26(74.3) \\
9(25.7)\end{array}$ & $\begin{array}{l}39(20.4) \\
10(79.6)\end{array}$ & 0.567 \\
\hline BMI, $\mathrm{kg} / \mathrm{m}^{2}$ & $27.5 \pm 2.7$ & $27.6 \pm 3$ & $27.5 \pm 2.5$ & 0.968 \\
\hline Systolic BP, mm Hg & $123 \pm 21$ & $120 \pm 19$ & $126 \pm 21$ & 0.215 \\
\hline Diastolic BP, mm Hg & $73 \pm 10$ & $72 \pm 10$ & $74 \pm 10$ & 0.374 \\
\hline Hypertension, \% & $38(45.2)$ & $18(51.4)$ & $20(40.8)$ & 0.170 \\
\hline Diabetes Mellitus, \% & $22(26.5)$ & $12(34.3)$ & $10(20.8)$ & 0.335 \\
\hline Hyperlipidemia, \% & $23(27.4)$ & $11(31.4)$ & $12(24.5)$ & 0.482 \\
\hline Smoking, \% & $48(57.1)$ & $23(65.7)$ & $25(51)$ & 0.180 \\
\hline CAD history, $\%$ & $9(10.7)$ & $2(5.7)$ & $7(14.3)$ & 0.210 \\
\hline Family history, \% & $13(15.5)$ & $5(14.3)$ & $8(16.3)$ & 0.799 \\
\hline Ejection fraction, $\%$ & $43 \pm 9$ & $42 \pm 7$ & $44 \pm 10$ & 0.413 \\
\hline Killip class, $2-3, \%$ & $8(9.5)$ & $4(11.4)$ & $4(8.2)$ & 0.615 \\
\hline Symptom onset duration & $2.6 \pm 1.4$ & $2.4 \pm 1.5$ & $2.8 \pm 1.4$ & 0.496 \\
\hline Hospitalization duration & $4.7 \pm 1.6$ & $4.4 \pm 1.9$ & $4.9 \pm 1.4$ & 0.243 \\
\hline \multicolumn{5}{|l|}{ MI localization } \\
\hline Anterior MI (\%) & $15(17.9)$ & $7(20)$ & $8(16.3)$ & \multirow{5}{*}{0.130} \\
\hline Anteroseptal, MI \% & $8(9.5)$ & $5(14.3)$ & $3(6.1)$ & \\
\hline Inferior MI, \% & $45(53.6)$ & $15(42.9)$ & $30(61.2)$ & \\
\hline Lateral MI, \% & $3(3.6)$ & $3(8.6)$ & $0(0)$ & \\
\hline Extensive Anterior MI, \% & $13(15.5)$ & $5(14.3)$ & $8(16.3)$ & \\
\hline
\end{tabular}

Data are represented as mean \pm standard deviation and $\mathrm{n}(\%)$.

2. STEMI patients diagnosed with a $>2-\mathrm{mm}$ $S T$ segment elevation in at least two consecutive chest derivations or a $>1-\mathrm{mm} S T$ segment elevation in extremity derivation.

3. Patients who had undergone thrombolytic or PCI intervention.

Exclusion Criteria. Patients with a serious concomitant disease, cancer diagnosis, active inflammatory disease, renal insufficiency (creatinine clearance $<60 \mathrm{~mL} / \mathrm{min}$ ), myocarditis, and pulmonary embolism, and patients exposed to trauma were excluded.

The cTn-I levels were quantitatively measured in venous blood samples of patients at the time of admission and at 2, 4, and $6 \mathrm{~h}$ after admission by chemiluminescence (Abbott-Architect 1000 device).The delta troponin I coefficient was calculated by dividing the difference of cTn-I at time interval of $0-2,0-4$, and $0-6 \mathrm{~h}$ by basal troponin levels [(follow-up troponin-basal troponin)/basal troponin]. The patients below and above the median value were separated into two groups and the difference between the in-hospital cardiovascular endpoints between the groups was investigated. Thrombolytic treatment and primary PCI patients were compared in the sub-group analysis.

Statistical Analysis. Statistical analyses were performed using SPSS 18.0 computer statistics package software. Categorical variables are represented as either numbers or percentages, and continuous variables are represented as mean \pm standard deviation (SD). A chi-square test was used for comparing categorical variables. For comparing continuous variables, first, parameters were checked for normality of distribution by using the Kolmogorov-Smirnov test. A Mann-Whitney $\mathrm{U}$ test was used for comparing non-normally distributed data between the two groups. An independent sample t-test was used for comparing the data with normal distribution. $\mathrm{p}<0.05$ was considered statistically significant.

Results. Eighty-four patients (65 men, 19 women; mean \pm SD age: $58.9 \pm 11.9$ years; mini- 
Казанский медицинский журнал, 2019 г., том 100, №5

Table 2. Laboratory findings of the cases included in the study

\begin{tabular}{|l|c|c|c|c|}
\hline \multicolumn{1}{|c|}{ Parameters } & Total $(\mathrm{n}=84)$ & Thrombolytic $(\mathrm{n}=35)$ & PCI $(\mathrm{n}=49)$ & P value \\
\hline Creatinine, $\mathrm{mg} / \mathrm{dL}$ & $0.9 \pm 0.1$ & $0.88 \pm 0.1$ & $0.92 \pm 0.2$ & 0.316 \\
\hline Creatinine Clearance, $\left.\mathrm{mL} / \mathrm{min} / 1.73 \mathrm{~m}^{2}\right)$ & $102 \pm 27$ & $102 \pm 30$ & $100 \pm 25$ & 0.955 \\
\hline LDL-Cholesterol, $\mathrm{mg} / \mathrm{dL}$ & $125 \pm 49$ & $116 \pm 34$ & $131 \pm 57$ & 0.199 \\
\hline HDL-Cholesterol, $\mathrm{mg} / \mathrm{dL}$ & $40 \pm 9$ & $38 \pm 10$ & $41 \pm 9$ & 0.064 \\
\hline Hemoglobin, g/dL & $14 \pm 1.7$ & $13.8 \pm 2.1$ & $14.2 \pm 1.5$ & 0.422 \\
\hline PLT, K/mL & $269 \pm 64$ & $266 \pm 73$ & $272 \pm 57$ & 0.674 \\
\hline Albumin & $4.2 \pm 0.4$ & $4.2 \pm 0.4$ & $4.1 \pm 0.4$ & 0.274 \\
\hline Uric acid & $5.3 \pm 1.5$ & $5.1 \pm 1.4$ & $5.4 \pm 1.6$ & 0.487 \\
\hline Admission Blood Sugar & $170 \pm 79$ & $175 \pm 83$ & $166 \pm 77$ & 0.618 \\
\hline Admission Potassium & $4.2 \pm 0.4$ & $4.2 \pm 0.4$ & $4.3 \pm 0.4$ & 0.298 \\
\hline
\end{tabular}

Data are represented as mean \pm standard deviation.

Table 3. Delta value and in-hospital endpoints of the cases included in the study

\begin{tabular}{|c|c|c|c|c|c|c|c|c|c|}
\hline \multirow{2}{*}{$\begin{array}{c}\text { Parameters } \\
\text { MEDIAN VALUES }\end{array}$} & \multicolumn{2}{|c|}{$\begin{array}{c}\text { Delta cTn-I }(0-2), \\
n=84\end{array}$} & \multirow{2}{*}{$\mathrm{p}$} & \multicolumn{2}{|c|}{$\begin{array}{l}\text { Delta cTn-I }(0-4) \\
n=81\end{array}$} & \multirow{2}{*}{$\mathrm{p}$} & \multicolumn{2}{|c|}{$\begin{array}{l}\text { Delta cTn-I (0-6), } \\
\text { n }=79\end{array}$} & \multirow{2}{*}{$\mathrm{p}$} \\
\hline & $<21$ & $>21$ & & $<124$ & $>124$ & & $<193$ & $>193$ & \\
\hline Cardiovascular death & 6 & 1 & 0.056 & 3 & 1 & 0.317 & 2 & 1 & 0.602 \\
\hline Re-infarction & 0 & 0 & - & 0 & 0 & - & 0 & 0 & - \\
\hline Recurrent ischemia & 4 & 1 & 0.184 & 1 & 3 & 0.293 & 1 & 3 & 0.269 \\
\hline $\begin{array}{l}\text { Emergency } \\
\text { revascularization }\end{array}$ & 4 & 1 & 0.184 & 1 & 3 & 0.293 & 1 & 3 & 0.269 \\
\hline Cardiac insufficiency & 2 & 0 & 0.162 & 1 & 1 & 0.986 & 1 & 1 & 0.957 \\
\hline Cardiogenic shock & 6 & 1 & 0.056 & 3 & 1 & 0.317 & 2 & 1 & 0.602 \\
\hline Arrhythmia & 6 & 2 & 0.157 & 6 & 1 & 0.052 & 6 & 1 & 0.061 \\
\hline Stroke/TIA & 0 & 2 & 0.143 & 1 & 1 & 0.986 & 1 & 1 & 0.957 \\
\hline $\begin{array}{l}\text { Mechanical } \\
\text { complication }\end{array}$ & 1 & 0 & 0.326 & 1 & 1 & 0.320 & 1 & 0 & 0.333 \\
\hline
\end{tabular}

mum and maximum age: 33 and 84 years, respectively) receiving thrombolytic or primary PCI treatment for STEMI diagnosis were included and the relationship between delta troponin-I levels and in-hospital cardiovascular endpoints was studied.

Thirty-five (41.7\%) patients received thrombolytic treatment and $49(58.3 \%)$ patients received primary PCI treatment. Demographic, clinical, and laboratory characteristics of the included patients are provided in table 1 . No statistically significant difference was observed between thrombolytic and primary PCI treatment groups in terms of demographic and clinical characteristics $(\mathrm{p}>0.05)$. The reperfusion was achieved in $24(85.7 \%)$ patients receiving fibrinolytic treatment and $47(95.9 \%)$ patients with primary PCI treatment. No statistically significant difference was observed between thrombolytic and primary PCI treatment groups in terms of reperfusion $(\mathrm{p}>0.05)$.

The analysis of all patients and sub-groups of thrombolytic and primary PCI patients revealed no statistically significant difference between delta troponin I levels at time intervals of $0-2,0-4$, and $0-6 \mathrm{~h}$ and in-hospital major cardiovascular endpoints $(p>0.05)$.

Demographic and clinical properties (see table 1), Laboratory findings (table 2) and Delta value and in-hospital endpoints (table 3 ) are shown in tables 1-3.

Discussion. This study showed that cTn-I levels at the time of admission and at 2, 4, and $6 \mathrm{~h}$ after admission and delta troponin-I levels calculated from cTn-I levels are insufficient for predicting inhospital cardiovascular endpoints.

Delta troponin I levels were defined as the absolute and relative (percentage) changes in cTn-I 
levels at admission and at different hours after admission. In the literature, the studies with delta troponin often did not include STEMI patients and patient groups for whom thrombolytic therapy is chosen as reperfusion strategy were generally excluded from the studies.

Although a high cTn-I level is known to have a relation with poor prognosis, there are a limited number of studies that have assessed the relationship among early dynamic changes in cTn-I levels, prognosis, and clinical data. Such studies have been mainly conducted to test the direction that can provide diagnostic verification and differentiation in secondary causes in non-ST elevation acute coronary syndrome patients. Therefore, troponin monitoring with shorter intervals is recommended as novel approach instead of troponin monitoring with 6- to 8-hour intervals in acute coronary syndrome diagnosis through cTn-I levels [7-13].

In this regard, Reichlin et al (2011) evaluated the highly sensitive cTn-T and cTn-I parameters measured at the time of admission and at 1 and $2 \mathrm{~h}$ after admission in 836 patients with acute myocardial infarction (AMI). The authors claimed that absolute changes could be more valuable than relative changes for diagnostic verification in AMI patients and that absolute changes could be more important in terms of criteria for the differentiation of secondary causes that may also cause cTn-I elevation [5].

Apple et al. (1999) claimed that defining delta troponin I levels calculated by measuring cTn-I levels at the time of admission and at 6 and $24 \mathrm{~h}$ after admission increases the clinical specificity and diagnostic accuracy in patients admitted with symptoms of acute coronary syndrome and that these values could be used more effectively for risk evaluation [11].

Sanchis et al. (2015) measured h-cTnT in 601 patients who had acute coronary syndrome before diagnosis without $S T$-segment elevation at the time of admission and within first $6 \mathrm{~h}$ and determined maximum h-cTnT and delta $\mathrm{h}$-cTnT levels. The authors observed that patients with high maximum h-cTnT levels could have an abnormal angiogram and poor prognosis; patients with low maximum h-cTnT and delta h-cTnT levels had no significant coronary stenosis [14].

In the literature, there are no studies investigating the relationship of in-hospital and long-term clinical endpoints with prognosis in acute coronary syndrome patients by studying the delta troponin I parameter.

Therefore, we believe that our study is the first such one in the literature. We found no statistically significant difference between delta troponin levels and in-hospital endpoints for both of the groups. We attribute these findings to the higher cTn-I levels in STEMI patients compared toother acute coronary syndromes, as well as to variable increase in cTn-I levels depending on the location of MI, presence of apparent cTn-I increase despite the absence of complications in many cases, and the fact that cardiac cTn-I levels are affected by percutaneous coronary intervention.

Conclusion. In conclusion, the analyses of delta troponin levels are insufficient to predict in-hospital endpoints (outcomes) in patients with STEMI treated by a thrombolytic therapy or primary PCI. Randomized controlled studies with a large population are needed in this subject.

Limitations of the study. Because this was a single-center study, the results obtained cannot be generalized; multi-center prospective studies are needed. Another limitation is the small number of patients and the retrospective design of the study; therefore, it includes all the disadvantages of retrospective studies.

Acknowledgement. Ercan Aydın, Altug Osken, Huseyin Gunduz and Nurgul Keser monitored the patients, participated in study design, statistics and coordination and helped to interpret the data and to draft the manuscript. Ercan Aydin, Selcuk Yaylaci, Salih Sahinkus and Nurgul Keser participated in data analysis and interpretation and wrote the manuscript. Ercan Aydin, Salih Sahinkus, Altug Osken and Selcuk Yaylaci participated in the study design and statistics, oriented the data collection and revised the manuscript critically. All authors read and approved the final manuscript.

Funding sources. This study was not supported by any funding source. The authors do not have any conflict of interest to declare.

\section{REFERENCES}

1. Callow A.D. Cardiovascular disease 2005-theglobal Picture. Vascul. Pharmacol. 2006; 45: 3027. DOI: 10.1016/ j.vph.2006.08.010.

2. Murphy J.G., Lloyd M.A. Mayo Clinic Cardiology Textbook. Thirded. Mayo Clinic Scientific Pres. 2007; 843 p.

3. Wu A.H.B., Apple F.S., Gibler W.B. et al. National Academy of Clinical Biochemistry Standards of Laboratory Practice: recommendations for the use of cardiac markers in coronary artery diseases. Clin. Chem. 1999; 45: 11041121. PMID: 10388496.

4. Bassand J.P., Hamm C.W., Ardissino D. et al. Guidelines for the diagnosis and treatment of non-ST-segment elevation acute coronary syndromes. Task Force for Diagnosis and Treatment of Non-ST-Segment Elevation Acute Coronary Syndromes of European Society of Cardiology. Eur. Heart J. 2007; 28: 1598-1660. DOI: 10.1093/eurheartj/ehm499.

5. Reichlin T., Irfan A., Twerenbold R. et al. Utility of absolute and relative changes in cardiac troponin concentrations in the early diagnosis of acute myocardial infarc- 
tion. Circulation. 2011; 124: 136-145. DOI: 10.1161/CIR CULATIONAHA.111.023937.

6. Xiao W., Cao R., Liu Y. et al. Association of high-sensitivity cardiac troponin $\mathrm{T}$ with mortality and cardiovascular events in a community-based prospective study in Beijing. BMJ Open. 2017; 7 (6): e013431. DOI: 10.1136/ bmjopen-2016-013431.

7. Fesmire F.M. Delta CK-MB outperforms delta troponin I at 2 hours during the ED rule out of acute myocardial infarction. Am. J. Emerg. Med. 2000; 18: 1-8. DOI: 10.1016/ S0735-6757(00)90038-X.

8. Fesmire F.M., Hughes A.D., Fody E.P. et al. The Erlanger chest pain evaluation protocol: a one-year experience with serial 12-lead ECG monitoring, two-hour delta serum marker measurements, and selective nuclear stress testing to identify and exclude acute coronary syndromes. Ann. Emerg. Med. 2002; 40: 584-594. DOI: 10.1067/ mem.2002.129506.

9. Marin M.M., Teichman S.L. Use of rapid serial sampling of creatine kinase MB for very early detection of myocardial infarction of patients with acute chest pain. Am. Heart J. 1992; 123: 354-361. DOI: 10.1016/00028703(92)90646-D.

10. Young G.P., Gibler W.B., Hedges J.R. et al. Serial creatine kinase-MB results are a sensitive indicator of acute myocardial infarction in chest pain patients with nondiagnostic electrocardiograms: the second Emergency Medicine Cardiac Research Group Study. Acad. Emerg. Med. 1997; 4: 869-877. DOI: 10.1111/j.1553-2712.1997.tb03812.x.

11. Apple F.S., Christenson R.H., Valdes R.J. et al. Simultaneous rapid measurement of whole blood myoglobin, creatine kinase $\mathrm{MB}$, and cardiac troponin I by the triage cardiac panel for detection of myocardial infarction. Clin. Chem. 1999; 45: 199-205. PMID: 9931041.

12. Fesmire F.M., Percy R.F., Bardoner J.B. et al. Serial creatinine kinase (CK) MB testing during the emergency department evaluation of chest pain: utility of a 2-hour deltaCK-MB of $+1.6 \mathrm{ng} / \mathrm{ml}$. Am. Heart J. 1998; 136: $237-$ 244. DOI: $10.1053 /$ hj.1998.v136.89571.

13. Mueller M., Biener M., Vafaie M. et al. Absolute and relative kinetic changes of high-sensitivity cardiac troponin $\mathrm{T}$ in acute coronary syndrome and in patients with increased troponin in the absence of acute coronary syndrome. Clin. Chem. 2012; 58: 209-218. DOI: 10.1373/ clinchem.2011.171827.

14. Sanchis J., Abellan L., Garcia-Blas S. et al. Usefulness of delta troponin for diagnosis and prognosis assessment of non-ST-segment elevation acute chest pain. Eur. Heart J. Acute Cardiovasc. Care. 2016; 5: 399-406. DOI: $10.1177 / 2048872615593534$. 